\title{
POLEMIK "TULISAN ARAB" PADA BUSANA AGNES MONICA (ANALISIS TEORI INTERAKSIONISME SIMBOLIK)
}

\author{
Ihsanudin \\ Alumnus Interdisciplinary Islamic Studies Pascasarjana UIN Sunan Kalijaga Yogyakarta \\ Jl. Marsda Adisucipto Yogyakarta \\ E-mail: zanudinbsa@gmail.com
}

\begin{abstract}
Arabic is synonymous with the symbol of Islam. Because the Qur'an and Sunnah use Arabic Language. However, tren fashion is now entering the era of globalization. It doesn't matter if tren fashion is currently mixed with western and eastern cultures. Agnes Monica's dress, which when appearing on television shows, attracted controversy of many parties because it was considered taboo, because of the transparent clothing and Arabic writing that was right on her thigh. Various suggestions from nitizen fulfilled the social media homepage, MUI also commented on the polemic that had taken place. The Mead Symbolic Interactionism Theory is very appropriate to be used as a knife for analyzing the case above. The purpose of this study is to describe and analyze the phenomenon of Agnes Monica's dress Arab writing "Al-Muttahidah" using Mead's theory, include describing the specifically human social act, action, gesture, signicicant symbols, mean, self, and society. This research is belong to library research and use analytical descriptive methods.
\end{abstract}

Keywords: Tren Fashion, Arabic Writing, Mead's Symbolic Interactionism.

\begin{abstract}
Abstrak
Bahasa Arab sangat identik dengan simbol Islam. Karena Al-Qur'an dan As-Sunah menggunakan bahasa Arab. Disisi lain, tren busana saat ini sudah masuk era globalisasi. Tak hayal jika tren busana saat ini bercampur budaya barat dan timur. Busana Agnes Monica yang saat tampil di acara televisi menuai kontroversi dari berbagai pihak karena dianggap tabu, busana yang transparan dan tulisan Arab tepat dipahanya. Berbagai cuitan dari nitizen memenuhi beranda media sosial, MUI pun ikut mengomentari untuk menengahkan polemik yang terjadi. Teori Interaksionisme Simbolik Mead sangat tepat untuk dijadikan sebagai pisau analisis kasus di atas. Adapun tujuan penelitian ini ialah mendeskripsikan dan menganalisis fenomena busana Agnes Monica yang bertuliskan Arab "al-Muttahidah" dengan teori Mead, diantaranya menguraikan prioritas sosial, tindakan, sikap, simbol-simbol signifikan, pikiran (mean), diri (self), dan masyarakat. Penelitian ini termasuk penelitian kajian pustaka (library research) dengan metode deskriptif analitis.
\end{abstract}

Kata Kunci,: Tren Busana, Tulisan Arab, Interaksionisme Simbolik Mead.

\section{PENDAHULUAN}

Tiga tahun silam, tepatnya tanggal 11 bulan Januari 2016 salah satu media televisi swasta nasional menayangkan sebuah acara yang disemarakkan salah satu artis populer, Agnes Monica. Agnes Mo (panggilan akrabnya) merupakan satu satu kandidat wanita yang paling berpengaruh pada tahun 2007 diurutan 


\section{8 | Ihsanudin}

nomor 39.1 Tidak heran jika para fans-nya sangat banyak. Sudah tidak menjadi rahasia umum bahwa penampilannya di televisi sangat memukau. Namun disisi lain, penampilannya saat itu menuai kontroversi. Para nitizen di media sosial menilai dari sisi penampilan busananya tidak mencerminkan budaya timur. Jenis busana yang dipakai berjenis dress warna hitam, dan bertulisan Arab itu berbunyi "al-Muttahidah" (المتحدة) yang artinya "persatuan".2 Para nitizen banyak yang mengecamnya. Terlepas dari agama yang ia anut, secara terlihat busananya selain transparan juga kurang sopan dalam pandangan umum, bahwa busana yang dikenakan bertuliskan Arab pada bagian pahanya. Seperti terlihat foto di bawah ini ${ }^{3}$ :

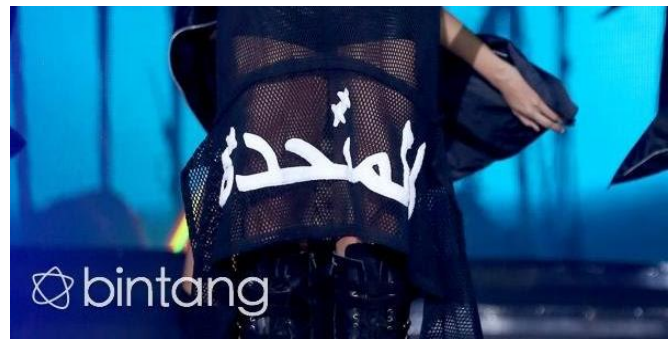

Gambar 1. Tulisan arab pada busana Agnes Monica

Dari peristiwa itu, Majelis Ulama Indonesia (MUI) angkat bicara mengenai tulisan bahasa Arab yang dikenakan Agnes Mo. Muhyiddin Junaidi dari MUI, kepada BBC Indonesia, mengatakan tidak setiap tulisan Arab adalah hadis Nabi, dan yang menggunakan bahasa Arab bukan hanya mereka yang beragama Islam. Muhyiddin mengatakan "Ada Yahudi, Kristen yang juga menggunakan bahasa Arab." Selain itu menurutnya salah kaprah terjadi karena ada orang-orang yang menganggap bahwa bahasa Arab sama sakralnya dengan al-Quran, "Padahal tidak seperti itu, ini yang perlu diluruskan" katanya. Lebih lanjut Muhyidin memberikan keterangan "Itu (artinya) kan ajakan bersatu, tidak masalah. Lain kalau itu ternyata penggalan ayat, memang tidak diperbolehkan dan termasuk penistaan agama." 4 Namun nitizen tetap mengecamnya, mengingat tulisan Arab begitu lekat dengan simbol Islam.

1https://id.m.wikipedia.org/wiki/Daftar_99_wanita_paling_berpengaruh_di_Indones ia (2007) diakses 2 Januari 2019 pukul 17.10 WIB.

2 Keterangan dari Cholil Nafis, selaku Ketua Dakwah MUI Pusat, lihat https://www.google.com/amp/s/beritagar.id/artikel-amp/seni-hiburan/menyimak-

kontroversi-teks-arab-dalam-kostum-agnes-monica diakses 2 Januari 2019 pukul 11.12 WIB.

${ }^{3}$ http://www.bintang.com/celeb/read/2410337/mui-angkat-bicara-soal-tulisan-arab-dikostum-agnes-monica diakses 2 Januari 2019 pukul 11.16 WIB.

${ }^{4}$ Lihat

https://www.bbc.com/indonesia/majalah/2016/01/160113 trensosial_busana arab_agnes monica diakses 2 Januari 2019 pukul 11.10 WIB. 
Dalam hal ini penulis menggunakan teori Interaksionisme Simbolik George Herbert Mead. Mead adalah pemikir yang sangat penting dalam sejarah Interaksionisme Simbolik dan bukunya yang berjudul Mind, Self, and society adalah karya tunggal yang amat penting dalam tradisi itu. ${ }^{5}$ Fenomena yang terjadi dalam kasus di atas merupakan fakta sosial (meminjam perkataan Durkheim) mengingat bahwa masyarakat bukan hanya sekelumit pemikiran yang dalam kepala seseorang, tapi sekian banyak fakta, termasuk bahasa. ${ }^{6}$

Pertanyaan yang penulis ajukan adalah "Bagaimana teori Interaksionisme Mead dalam memandang fakta sosial yang terjadi seperti dalam kasus Agnes Mo di atas?". Penulis menggunakan teori Interaksionisme Simbolik Mead karena teori ini sesuai untuk diterapkan pada fenomena diatas.

\section{METODE}

Jenis penelitian ini adalah kajian pustaka (library research) yang mana peneliti mengumpulkan data baik dari sumber media elektronik maupun cetak. Adapun objek material diambil dari internet, yaitu mengambil beberapa informasi dari web yang dapat dipercaya. Setelah data terkumpul, peneliti menginventarisir data sesuai kebutuhan, mengamati dan menganalisis sesuai teori yang dipakai kemudian menguraikan secara deskriptif analitis.

\section{A. BIOGRAFI SINGKAT GEORGE HERBERT MEAD}

George Herbert Mead dilahirkan di South Hatley Massachusetts 27 Februari 1863, Mead mendapatkan pendidikan terutama di bidang filsafat dan aplikasinya terhadap kajian psikologi sosial. Mendapat sarjana muda dari Oberlin College (tempat ayahnya menjadi profesor) di tahun 1883 dan beberapa kemudian, menjadi guru dasar, menjadi mantri ukur di perusahaan KA dan memberikan les privat. Tahun 1887 Mead meneruskan pendidikan di Harvard maupun di Universitas Leipzig dan Berlin, Mead ditawari menjadi dosen di universitas Michigan tahun 1891. Mead tak pernah mendapatkan gelar sarjana (S-1). Tahun 1894, atas undangan John Dewey, ia pindah ke Universitas Chicago dan tetap di situ hingga akhir hayat. ${ }^{7}$

\section{B. BAHASA SEBAGAI KOMUNIKASI DAN "SIMBOL AGAMA"}

Salah satu fungsi bahasa adalah untuk komunikasi, baik berupa tuturan ataupun tulisan, simbolik, maupun alfabetik, memiliki arti ataupun tidak

\footnotetext{
5 Goorge Ritzer, Teori Sosiologi Modern, edisi ke tujuh, penerjemah Triwibowo, buku asli berjudul Modern Sociological Theory: Seventh Edition, (Jakarta: Kencana, 2014), hlm. 256.

6 Daniel El Pals, Dekontruksi Kebenaran: Kritik Tujuh Teori Agama, penerjemah: Inyiak Ridwan Muzir, M Syukri, penyunting: Edi AH Iyubenu, buku asli berjudul Seven Theories of Religion, cet. Ke-3, (Yogyakarta: ICRSoD, 2003), hlm. 139.

7 Daniel El Pals, Dekontruksi Kebenaran: Kritik Tujuh Teori Agama...,hlm. 259.
} 


\section{0 | Ihsanudin}

memiliki arti. Heidegger berpendapat bahwa logos adalah hal yang disampaikan ketika orang berbicara, sedangkan makna esensial logos adalah sesuatu yang membiarkan dirinya sebagai penampakan. Salah satu peran medium ialah terciptanya efek pembesaran suatu objek, inilah yang dinamakan eskalasi. Medium menggunakan bahasa. Eskalasi menghasilkan image pemaknaan agama (jika objeknya agama) yang mendorong terjadinya pemahaman umum (common sense) religiusitas secara mendalam/ menyangatkan. Paul Tillich (1886-1965) memberikan suatu cara untuk membedakan "bahasa Agama", dan "simbol", serta titik temu di antara keduanya. Menurut Tillich (1996:357), bahasa agama tidak bis a dipahami secara literer saja, tetapi harus dipahami secara simbolis. Simbol dapat diartikan "tanda" untuk menyampaikan satu maksud, sekaligus menunjukkan suatu makna yang dituju. Simbol berkaitan dengan agama sebagaimana digunakan untuk alat pernyataan, misalnya bahasa teks suci lafadz Allah (dalam aksara Arab). Di mana pun aksara ini ditempatkan, common sense dengan mudah mengambil kesimpulan: "Islam". Identitas Islam sangat mudah untuk diidentifikasi berdasarkan simbol-simbol. ${ }^{8}$

\section{ANALISIS MEAD}

Menurut Goerge Herbert Mead, agar interaksi sosial bisa berjalan dengan tertib dan teratur dan agar anggota masyarakat bisa berfungsi secara "normal", maka diperlukan bukan hanya kemampuan untuk bertindak sesuai dengan konteks sosialnya, tetapi juga memerlukan kemampuan untuk menilai secara objektif perilaku kita sendiri dari sudut pandang orang lain. ${ }^{9}$ Ada 7 hal yang menjadi fokus Interaksionisme simbolik menurud Mead, diantaranya:

\section{Prioritas Sosial}

Pandangan Mead dalam memandang pengalaman sosial tidak terlepas dari psikologi sosial tradisional, yaitu memulainya dari psikologi individual; sebaliknya, Mead selalu memberikan prioritas pada kehidupan sosial dalam memahami pengalaman sosial. Mead menjelaskan demikian:

"Menurut psikologi sosial, keseluruhan (masyarakat) adalah lebih dahulu daripada bagian (individu), bukannya bagian adalah lebih dahulu daripada keseluruhan; dan bagian itu diterangkan dari sudut keseluruhan, bukan keseluruhan yang diterangkan dari sudut pandang bagian atau bagianbagian".

Dari pernyataan Mead di atas, perkumpulan individu yang membentuk sosial lebih didepankan dahulu daripada pemikiran

8 Hudjolly, Imagologi: Strategi Rekayasa Teks, (Yogyakarta: Ar-Ruzz Media, 2011), hlm. 60-63.

9 Dwi Narwoko, Bagong Suyanto, Sosiologi, Teks Pengantar dan Terapan, edisi kedua, cet.3, (Jakarta: Kencana, 2007), hlm. 20-21. 
individual. Karena sebenarnya individual adalah bagian terkecil dari kehidupan sosial. Kehidupan sosial muncul terlebih dahulu dari Individu, sehingga individu dapat berpikir bahwa dirinya adalah bagian dari sosial. Kehidupan sosial memandang individu adalah bagiannya.

Dari keterangan di atas, prioritas sosial lebih diutamakan terlebih dahulu dibanding dengan kepentingan individual, karena sejatinya kehidupan sosial lahir sebelum individual membentuk kesadaran diri. Menurut teori di atas sangat tepat pada kasus yang menimpa Agnes Mo. Penulis mengibaratkan kehidupan sosial yang diprioritaskan adalah masyarakat luas yang menonton acara televisi, termasuk nitizen. Agnes Mo manggung dengan busana dres panjang transparan, bertuliskan Arab, dan tidak termasuk budaya Indonesia. ${ }^{10}$ Mengingat bahwa busana yang dikenakan cenderung terbuka, dan bukanlah ciri adat ketimuran (baca: masyarakat Indonesia). ${ }^{11}$ Sedangkan yang mewakili individual tidak lain adalah Agnes Mo sendiri. Ia memandang pada dirinya tanpa memperhatikan kelompok sosial yang menilainya, kesadaran diri yang dibangun Agnes Mo dan logika yang ia pakai tidak memperhatikan aspek yang lain, bahwa saat ia tampil tidak hanya yang menonton di podium melainkan masyarakat luas seluruh Indonesia. Sehingga teori ini tepat bahwa harus memperioritaskan masyarakat sosial daripada kepentingan individual yang merupakan bagian dari kelompok sosial.

\section{Tindakan}

Mead memandang tindakan sebagai "unit primitif" dalam teorinya. Dalam menganalisis tindakan, pendekatan Mead hampir sama dengan pendekatan behavioris dan memusatkan perhatian pada ransangan (stimulus) dan tanggapan (response). Tetapi, stimulus di sini tidak menghasilkan respons manusia secara otomatis dan tanpa dipikir. Seperti dikatakan Mead "kita membayangkan stimulus sebagai sebuah kesempatan atau peluang untuk bertindak, bukan sebagai paksaan atau perintah" (1982: 28). Ada empat tindakan menurut Mead yang saling berhubungan, keempat tindakan itu mencerminkan satu kesatuan organik (berhubungan secara dialektis), keempat tindakan tersebut diantaranya ${ }^{12}$ :

10 Lihat http://www.suara.com/entertainment/2016/01/12/184537/pernyataan mui-soal-heboh-tulisan-arab-di-busana-agnez-mo diakses 2 Januari 2019 pukul 11.14 WIB. "Saya tidak senang melihat busana Agnes yang vulgar dan jauh dari budaya Indonesia. Namun, tulisan Arab di busananya tidak berarti menodai kesucian Islam," kata Ketua Dakwah MUI Pusat Cholil Nafis

11 Lihat http://www.bintang.com/celeb/read/2410337/mui -angkat-bicara-so al tulisan-arab-di-kostum-agnes-monica diakses 2 Januari 2019 pukul 11.14 WIB.

12 Goorge Ritzer, Teori Sosiologi Modern...,hlm. 257. 


\section{2 | Ihsanudin}

a. Impuls

Ialah dorongan hati/ impuls (impulse) yang meliputi "stimulasi"/ rangsangan spontan yang berhubungan dengan alat "indra" dan reaksi aktor terhadap rangsangan, kebutuhan sesuatu untuk rangsangan itu. Rasa lapar adalah contoh dari impuls. Aktor adalah manusia secara spontan dan tanpa pikir memberikan reaksi atas impuls, dan biasanya aktor manusia merangsang lebih tepat dalam memikirkan reaksi itu, contoh makan sekarang atau nanti. Dalam berpikir tentang reaksi manusia tak hanya mempertimbangkan situasi kini, tetapi juga pengalaman masa lalu dan mengantisipasi akibat tindakan di masa depan. secara menyeluruh, impuls, seperti unsur teori Mead, melibatkan aktor dan lingkungan. ${ }^{13}$

Dalam kasus Agnes Mo, antara Impuls atau rangsangan dengan reaksi yang ia peroleh tidak memikirkan atau mempertimbangkan halhal yang lain atas tindakannya. Terkait busana yang ia kenakan, salah satu penggemarnya menyanggah bahwa tulisan itu tidak bermaksud melecehkan atau merendahkan agama. ${ }^{14}$ Maksud tulisan Arab yang tertulis dibusananya bukanlah bahasa Arab yang ada di al-Qur'an sebagaimana orang menilainya. Tulisan "المتحدة" yang dalam bahasa Inggrisnya United diartikan dalam bahasa Indonesia sebagai Persatuan. ${ }^{15}$ Jadi menurutnya hal tersebut wajar saja, bahwa ia mendemonstrasikan "Persatuan" dalam busananya.

Aktor dalam hal ini adalah Agnes Mo, sedangkan lingkungan adalah masyarakat Indonesia. Berbagai agama, suku, dan etnis sangat bermacam-macam. Tindakan Agnes Mo (impuls) terhadap lingkungan yang mengitarinya dirasa kurang tepat ${ }^{16}$, rangsangan yang ia yakini tepat (bahwa kata Arab yang melekat dalam bajunya adalah sebuah tren busana masa kini) meskipun tulisan Arab tidaklah hanya tulisan di al-Qur'an saja. ${ }^{17}$ Namun, yang menjadi catatan dalam teori tindakan

13 Goorge Ritzer, Teori Sosiologi Modern ...,hlm. 257.

14 Greysa mengomentari pada 14 Jan 2016 pukul 20:48 "sah sah aja, itukan gak melecehkan, terserah bukan sih huruf arab mau dipake kapan aja??". Lihat https://www.google.com/amp/s/m.liputan6.com/amp/2410284/mui-kom entari-bajuberbahasa-arab-agnes-monica diakses 2 Januari 2019 pukul 11.15 WIB.

15 Komentar dari MUI Pusat, Cholil Nafis "Tulisan Arab di busananya tak berarti menodai kesucian Islam. Karena tulisan itu bukan ayat Alquran. Kata al muttahidah itu artinya (persatuan)". Lihat https://www.google.com/amp/s/m.liputan6.com/amp/2410284/mui komentari..., diakses 2 Januari 2019 pukul 11.15 WIB.

16 Kurang tepat karena lingkungan masyarakat di Indonesia mayoritas beragama Islam, meski tidak ada hubungan secara langsung dengan busana yang Agnes Mo pakai. Namun yang terasa dampaknya bagi para pemeluk agama Islam. Tidak lain karena busana yang dipakai bertuliskan bahasa Arab, meskipun tulisan itu bukanlah tulisan bagian dari ayat al-Qur'an.

17 Agnes Mo memberikan komentar dalam akun Twitter, @agnezmo, dia mengatakan bahwa itu adalah kesalahannya dan dia tidak mau terjebak dalam debat yang bodoh. 
Mead adalah aktor juga harus memperhatikan lingkungannya, tanpa lingkungan yang mendukungnya seorang aktor akan mendapatkan masalah. Dalam kasus ini Agnes Mo mendapatkan kritikan yang tajam dari nitizen dan MUI. Jika MUI menyoroti pada busananya yang terlalu vulgar, tidak sesuai adat busana ketimuran, dan transparan, sedang nitizen menitikberatkan pada busana Agnes Mo yang bertuliskan bahasa Arab. Meskipun MUI sudah menjelaskan bahwa tulisan Arab tersebut tidak sedikit pun menodai kesucian Islam. ${ }^{18}$

b. Persepsi

Aktor menyelidiki dan bereaksi terhadap rangsangan yang berhubungan dengan impuls. Manusia mempunyai kapasitas untuk merasakan dan memahami stimuli melalui pendengaran, senyuman, rasa, dan sebagainya. Persepsi melibatkan rangsangan yang baru masuk maupun citra mental yang ditimbulkannya. Aktor tidak secara spontan menanggapi stimuli dari luar, tetapi memikirkannya sebentar dan menunainya melalui bayangan mental. Artinya, sebuah rangsangan mungkin mempunyai beberapa dimensi dan aktor mampu memilih di antaranya. Aktor biasanya dihadapkan pada pilihan, dan mempunyai kapasitas untuk memilih yang mana perlu diperhatikan dan yang perlu diabaikan. ${ }^{19}$

Aktor dalam hal ini adalah Agnes Mo sendiri yang mampu membaca dan merasakan impuls dari lingkungannya yaitu berupa kritikan-kritikan tentang busanannya. Teori persepsi di atas, Agnes Mo tidak memfikirkan tindakannya kedepan, tendensinya bahwa seperti yang sudah penulis singgung di atas, bahwa ia menganggap tulisan Arab itu hanyalah tulisan biasa yang berarti United "persatuan", jadi menurutnya tidak apa-apa, selain itu maraknya busana tren sekarang yang bersablon tulisan Arab. Ia memperhatikan hal itu sebagai fenomena biasa dan juga memperhatikan apa yang perlu diabaikan (tulisan Arab dianggapnya sebagai tulisan-tulisan lain, seperti tulisan bahasa Inggris, misal: United). Menanggapi halitu, Agnes Mo berlebihan dalam hal persepsinya sebagai individu, persepsi yang muncul dari

\footnotetext{
"Berburuk sangka bukan metode saya, i'm out". Ia menambahkan"Saya tidak takut karena Tuhan itu adil. Sungguh arogan kalau saya berani menunjuk orang sementara saya masih banyak kekurangan."

Lihat

https://www.bbc.com/indonesia/majalah/2016/01/160113 trensosial_busana_arab_agnes monica diakses 2 Januari 2019 pukul 11.16 WIB.

18 Komentar Cholil Nafis "Saya tidak senang melihat busana Agnes yang vulgar dan jauh dari budaya Indonesia. Namun tulisan Arab di busananya tak berarti menodai kesucian Islam". Lihat https://www.google.com/amp/s/m.bintang.com/amp/2410337/mui-angkatbicara-soal-tulisan-arab-di-kos tum-agnes-monica diakses 2 Januari 2019 pukul 11.16 WIB..

19 Goorge Ritzer, Teori Sosiologi Modern...,hlm. 257.
} 


\section{4 | Ihsanudin}

faktor eksternal lebih besar dampaknya. Meski dalam teori persepsi, aktor tidak secara spontan menanggapi stimuli dari luar. Tetapi memikirkannya sebentar dan menilainya melalui bayangan. Lalu muncul persepsi baru bagi Agnes Mo, bahwa busana yang ia pakai pada saat mengisi acara disalah satu acara televisi bukanlah kebetulan, ia sudah memikirkan dalam dirinya, busana yang bersablon Arab itu bukan tulisan ayat al-Qur'an.

\section{c. Manipulasi}

Setelah impuls menyatakan pada dirinya sendiri dan objek telah dipahami, langkah selanjutnya adalah memanipulasi objek atau mengambil tindakan berkenaan dengan objek itu. Perlakuan terhadap objek yang diperoleh ia mulai memikirkan hal apa yang terjadi jika ia mengambilnya atau membuangnya. Dalam benaknya ia selalu memikirkan baik tidaknya mengambil objek itu, lebih berhati-hati, oleh karena itu ia selalu mempertimbangkan hal lain, baik masa lalu dan masa depan dilibatkan. Semacam ini aktor secara mental menguji berbagai macam hipotesis tentang apakah yang terjadi jika ia mengambil objek itu, dan sebaliknya. Selain itu aktor juga mempunyai sarana lain seperti tangan yang memungkinkan memanipulasi objek jauh lebih cerdik ketimbang yang dapat dilakukan binatang. ${ }^{20}$

Manipulasi objek yang terjadi dalam kasus Agnes Mo adalah ia memanfaatkan teknologi yang ada, sebenarnya ia tidak mau menanggapi nitizen yang banyak mengkritiknya (sangat dimungkinkan Agnes Mo menganggap nitizen hanya orang-orang biasa/ masyarakat umum). ${ }^{21}$ Dengan teknologi yang ada ia memanfaatkan Twiternya untuk membalas dan mengomentari terkait busana yang ia pakai. Ia mengatakan bahwa tulisan itu bermakna United "persatuan", kalimat setelahnya ia tidak ingin panjang lebar memperdebatkan tulisan itu. Dalam teori manipulasi ini menyatakan bahwa setelah aktor mengetahui impuls dan objek, ia dapat memanipulasi objek dan mengambil tindakan dengan hati-hati, benar bahwa Agnes Mo tidak ingin panjang lebar membahas hal-hal yang dianggap sepele seperti masalah busananya.

d. Konsumasi (consummation)

Tahap selanjutnya adalah tahap pelaksanaan/ konsumasi (consummation), atau mengambil tindakan yang memuaskan

\footnotetext{
20 Goorge Ritzer, Teori Sosiologi Modern...,hlm. 260.

21 BBC Indonesia melihat pengguna tampaknya cenderung tidak mempermasalahkan 'busana Arab' tersebut dan justru mengkritik balik orang-orang yang melontarkan tuduhan penistaan agama terhadap Agnes Monica. Lihat https://www.bbc.com/indonesia/majal ah/2016/01/160113 trensosial_busana arab_agnes monica diakses 2 Januari 2019 pukul 11.16 WIB.
} 
dorongan hati yang sebenarnya. ${ }^{22}$ Tindakan konsumasi hemat penulis ialah berawal dari rangsangan, kemudian menimbulkan persepsi, lalu melakukan manipulasi terhadap objek, maka konsumasi lebih mengarah pada tindakan yang nyata (real action).

Kasus Agnes Mo pada ujungnya, ia melakukan tindakan yang membuatnya sudah puas, ia tak menghiraukan cibian dari luar dan lebih fokus pada hal lain. Komentar yang ia berikan di twiternya, bahwa ia hanya memberikan sanggahan yang cukup singkat, tulisan itu artinya United dan ia tidak mau memperdebatkannya lagi. Langkah ini menurutnya sudah final. ${ }^{23}$

Dari keempat langkah di atas berjalan secara dialektis, membentuk proses organis dan Mead melihatnya seperti itu. menurutnya segi-segi setiap bagian yang muncul sepanjang waktu mulai dari awal hingga akhir tindakan sehingga dengan demikian setiap bagian mempengaruhi bagian lain. Jadi, tahap terakhir tindakan mungkin menyebabkan munculnya tahap yang lebih awal. Penulis menggambarkannya seperti ini: Agnes Mo menganggap tulisan Arab di busannya adalah biasa saja, hanya mengandung arti United "persatuan". Tapi mengapa tidak langsung menuliskan saja kata United di busananya, dan kenapa harus menggunakan bahasa Arab yang dipersepsikan mayoritas muslim itu adalah bahasa al-Qur'an, dan kenapa ia mencantumkan tulisan Arab melekat pada dirinya. Pertanyaan demi pertanyaan muncul yang harus dijawab secara kritis, jauh dari persepsi bahwa Agnes Mo beragama non Islam.

\section{Sikap (Gesture)}

Gerak/ sikap isyarat menurut Mead adalah mekanisme dasar dalam tindakan sosial dan dalam proses sosial yang lebih umum. Sementara tindakan hanya melibatkan satu orang, tindakan sosial melibatkan dua orang atau lebih. Sedang kata Gesture menurut Mead adalah gerakan organisme pertama yang bertindak sebagai rangsangan khusus yang menimbulkan tanggapan (secara sosial) yang tepat dari organisme ke dua. Manusia mampu membuat isyarat tanpa pikir dan secara otomatis mendapatkan reaksi dari individu lain. ${ }^{24}$

22 Goorge Ritzer, Teori Sosiologi Modern...,hlm. 261.

23 Dalam akun Twitter, @agnezmo, " You know what, my bad. i just realized i got cought up in a stupid debate. love and forgive. Buruk sangka bukan metode saya. I'm OUT". Ia mengatakan bahwa itu adalah kesalahannya dan dia tidak mau terjebak dalam debat yang bodoh. "Berburuk sangka bukan metode saya, i'm out," "Saya tidak takut karena Tuhan itu adil. Sungguh arogan kalau saya berani menunjuk orang sementara saya masih banyak kekurangan."Lihat https://www.bbc.com/indonesia/majal ah/2016/01/160113 trensosial..., diakses 2 Januari 2019 pukul 11.16 WIB.

24 Goorge Ritzer, Teori Sosiologi Modern ...,hlm.262. 
Tanpa disadari Agnes Mo telah melakukan isyarat sebagai makhluk individu, ia melakukan tindakan memakai busana yang bertuliskan Arab hanya untuk dirinya. Sedangkan sikap/ tindakan sosial yang melibatkan banyak orang ia abaikan. Rangsangan ia peroleh adalah bentuk dari tindakannya secara individual, tanpa dipengaruhi faktor lain (rangsangan khusus), hal ini menimbulkan tanggapan (secara sosial), dan mendapatkan reaksi dari individu lain. Begitupun saat Agnes Mo selesai manggung, sebagian nitizen menilai tindakan Agnes Mo itu menghina Islam dan gila. ${ }^{25}$ Meski banyak kritikan yang dilontarkan akibat dari tindakan Agnes Mo, nitizen ada yang menerima sebagai hal yang biasa dan ada yang masih tetap tidak terima meski sudah mendapatkan keterangan terkait busana yang ia pakai. Namun, demikian individu satu dengan yang lain belum terima atas tindakannya yang mereka nilai senonoh. Busana yang transparan (tidak termasuk budaya ketimuran) dengan bertuliskan Arab dibawah busananya. ${ }^{26}$

\section{Simbol-simbol Signifikan}

Simbol signifikan adalah sejenis gerak isyarat yang hanya dapat diciptakan manusia. Isyarat menjadi simbol signifikan bila muncul dari individu yang membuat simbol-simbol itu sama dengan sejenis tanggapan (tetapi tidak selalu sama) yang diperoleh dari orang yang menjadi sasaran isyarat. Isyarat fisik dapat menjadi simbol yang signifikan, namun secara ideal tidak cocok dijadikan simbol signifikan karena orang tak dapat dengan mudah melihat atau mendengarkan isyarat fisiknya sendiri. Kumpulan yang paling mungkin menjadi simbol yang signifikan adalah bahasa: "simbol yang menjawab makna yang dialami individu pertama dan yang mencari makna dalam individu kedua". Isyarat suara yang mencapai situasi seperti itulah yang dapat menjadi bahasa. Yaitu bahasa yang signifikan dan memberitahukan makna tertentu. Dalam percakapan dengan isyarat, hanya isyaratitu sendiri yang dikomunikasikan. Tetapi dengan bahasa, yang dikomunikasikan adalah isyarat dan maknanya. ${ }^{27}$

Fungsi bahasa atau simbol yang signifikan pada umumnya adalah menggerakkan tanggapan yang sama di pihak individu yang berbicara dan juga di pihak lain. Pengaruh lain dari bahasa adalah

\footnotetext{
25 Sejumlah kicauan mempertanyakan mengapa tulisan Arab itu dipakai dan lainnya menganggap bahwa itu 'seperti menghina Islam' dan 'gila'. Lihat https://www.bbc.com/indonesia/majalah/2016/01/160113 trensosial..., diakses 2 Januari 2019 pukul 11.16 WIB.

${ }^{26}$ Lihat https://www.bbc.com/indonesia/majalah/2016/01/160113 trensosial..., diakses 2 Januari 2019 pukul 11.16 WIB.

27 Goorge Ritzer, Teori Sosiologi Modern...,hlm. 263.
} 
merangsang orang yang berbicara dan orang yang mendengarnya. Orang yang meneriakkan "kebakaran" di dalam bioskop yang padat penonton setidaknya akan bergegas keluar sebagaimana halnya dengan orang yang mendengar teriakannya. Jadi, simbol signifikan memungkinkan orang menjadi stimulator tindakan mereka sendiri.

Dengan teori simbol-simbol signifikan di atas dapat diketahui isyarat dalam kasus Agnes Mo adalah simbol "tulisan Arab". Makna yang diberikan oleh Agnes Mo dengan nitizen sangat berbeda, dari sudut mana memandangnya. Jika Agnes Mo menganggap tulisan Arab itu biasa saja, berbeda dengan apa yang ditangkap oleh nitizen bahwa tulisan Arab termasuk digunakan dalam al-Qur'an (pandangan orang umum). Dengan adanya makna demikian, Agnes Mo sebagai aktor mengetahui bahwa tulisan Arab dalam busananya itu mengarah pada kontroversi, sehingga hal ini menjadi pelajaran baginya. Disinilah letak isyarat dan makna simbol-simbol signifikan di atas. Nitizen juga memperolehnya demikian, tulisan Arab yang mereka anggap "agung, sakral" karena al-Qur'an ditulis dengan bahasa Arab, mereka jadi tahu simbol isyarat dan makna tulisan Arab tidak selalu dianggap sakral, ada pula agama lain menggunakan bahasa Arab dalam percakapan atau tulis menulis.

\section{Pikiran (Mind)}

Pikiran dalam pengertian Mead adalah proses percakapan seseorang dengan dirinya sendiri, tidak ditemukan di dalam diri individu; pikiran adalah fenomena sosial. Pikiran muncul dan berkembang dalam proses sosial dan merupakan bagian integral dari proses sosial. Proses sosial mendahului pikiran, proses sosial bukanlah produk dari pikiran. Jadi, pikiran juga didefinisikan secara fungsional ketimbang secara subtantif. Melakukan sesuatu beraarti memberi respons terorganisasi tertentu; dan bila seseorang mempunyai respon itu dalam dirinya, ia mempunyai apa yang kita sebut pikiran. Mead juga melihat pikiran secara pragmatis, yaitu pikiran melibatkan proses berpikir yang mengarah pada penyelesaian masalah. Dunia nyata penuh dengan masalah dan fungsi pikiranlah untuk mencoba menyelesaikan masalah dan memungkinkan orang beroperasi lebih efektif dalam kehidupan. ${ }^{28}$

Mengarah pada kasus yang terjadi pada Agnes Mo, pikiran memainkan peranan penting dalam menentukan tindakan. Apa yang dilakukan Agnes Mo harusnya ia juga mengetahui tindakan setelah apa yang ia lakukan. Pikiran oleh seorang individu dalam hal ini adalah

\footnotetext{
28 Goorge Ritzer, Teori Sosiologi Modern...,hlm. 265.
} 


\section{8 | Ihsanudin}

Agnes Mo dengan kejadian yang menimpa dirinya, kritikan-kritikan dari nitizen sebagai proses sosial yang merupakan bagian integral yang tidak dapat dipisahkan darinya. Maka subtansi dari berpikir adalah mempunyai respon timbal balik dari organisasi tertentu (para nitizen). Dengan adanya komentar-komentar dari media sosial Agnes Mo menganggapnya sebagai masalah, karena mengganggu pikirannya. Maka secara spontan pikiran merespon untuk segera menyelesaikan permasalahan yang terjadi. Ia segera memberikan tanggapan terkait busana yang ia pakai saat manggung dan ia tidak menganggap itu sebagai perdebatan yang harus diselesaikan lama-lama. Pikiran merespon dengan baik dan menentukan permasalahan itu cukup diselesaikan secara baik-baik.

\section{Diri (Self)}

Pada dasarnya diri adalah kemampuan untuk menerima diri sendiri sebagai sebuah objek. Diri adalah kemampuan khusus untuk menjadi subjek maupun objek. Diri mensyaratkan proses sosial: komunikasi antarmanusia. Melalui aktivitas dan hubungan sosial diri dapat muncul dan berkembang. Lebih sederhananya, diri dapat bertahan dengan lingkungan sosial yang dihadapinya. Diri juga tak terlibat dalam tindakan yang dilakukan karena kebiasaan atau dalam pengalaman fisiologis spontan tentang kesakitan atau kesenangan. Menurut Mead tidak dikatan tubuh sebagai diri dan baru menjadi diri bila pikiran telah berkembang. Maka dari itu diri juga berhubungan secara dialektis dengan pikiran. Mekanisme mengembangkan diri adalah refleksitas atau kemampuan menempatkan diri secara tidak sadar ke dalam tempat orang lain dan bertindak seperti mereka bertindak. $^{29}$

Pengalaman yang dialami oleh Agnes Mo adalah kali pertamanya, sebagai diri yang dalam teori di atas berproses dan menempatkan pada lingkungannya, Agnes Mo berpikir bahwa dirinya mungkin benar dan mungkin salah. Dari sudut agama, bahasa Arab merupakan bahasa yang dipilih oleh Allah sebagai bahasa al-Qur'an agar orang-orang berpikir (Qs. Yusuf:2), dari ilmu pengetahuan bahasa Arab merupakan salah satu dari sekian ribu bahasa di dunia. Dalam diri Agnes Mo, tulisan Arab tak jauh berbeda dengan tulisan bahasa lain. Namun, karena konteks lingkungan sosial yang ada, mayoritas masyarakat Indonesia beragama Islam. Bahasa Arab adalah bahasa agama, bahasa al-Qur'an dan itu penting bagi mereka. diri dalam proses sosial merespon tulisan Arab di busana Agnes Mo tidak menerimanya

${ }^{29}$ Goorge Ritzer, Teori Sosiologi Modern ...,hlm. 265-266. 
sebagai tulisan yang biasa saja, karena bahasa adalah kesepakatan begitu juga bahasa Arab menurut mereka (mayoritas orang muslim) adalah bahasa al-Qur'an.

\section{Masyarakat}

Tingkat paling umum, Mead menggunakan istilah masyarakat (society) yang berarti proses sosial tanpa henti yang mendahului pikiran dan diri. Masyarakat penting peranannya dalam membentuk pikiran dan diri. Pada tingkat kemasyarakatan yang lebih khusus, Mead mempunyai sejumlah pemikiran tentang pranata sosial (sosial institutions). Secara luas, Mead mendefinisikan pranata sebagai "tanggapan bersama dalam komunitas" atau "kebiasaan hidup komunitas". Secara lebih khusus, ia mengatakan bahwa, "keseluruhan tindakan komunitas tertuju pada individu berdasarkan keadaan tertentu menurut yang sama, berdasarkan keadaan itu pula, terdapat respon yang sama di pihak komunitas". Namun, Mead dengan hati-hati mengemukakan bahwa pranata tak selalu menghancurkan individualitas atau melumpuhkan kreativitas. ${ }^{30}$

Melihat masyarakat media sosial (Nitizen) dengan individual yang diwakili Agnes Mo terdapat kesamaan teori di atas, bahwa tidak selamanya masyarakat/ pranata sosial menindas individual. Kritikan yang diberikan nitizen kepada Agnes Mo adalah salah satu bentuknya, nitizen menginginkan penjelasan Agnes Mo terkait dengan busana yang ia pakai. Nitizen tidak bermaksud menjelek-jelekan namanya di media sosial, mereka tak menginginkan tulisan Arab tersebut berada di busananya, apalagi dengan busana yang seperti itu (sangat transparan) dan tidak mencerminkan budaya ketimuran (baca Indonesia). Begitu juga, Nitizen juga tidak menghilangkan daya kreativitas busana modern sekarang yang banyak embel-embelannya, seperti tulisan Arab di berbagai busana tren yang lain. MUI telah mengingatkan bahwa tulisan Arab tidak semua dari al-Qur'an, namun untuk menjaga keadaban dan norma beda agama, seharusnya mengerti akan hal itu, menghormati agama lain sebagaimana tertuang dalam UUD 1945.

\section{PENUTUP}

Fenomena tren busana saat ini menjadi fenomena sosial yang berkembang pesat. Busana bertuliskan Arab "al-Muttahidah" (المتحدة) yang dipakai artis ternama, Agnes Mo dianalisis dengan teori Interaksionisme Simbolik Mead menurut penulis sangat tepat. Mead melihat interaksionisme sebagai hubungan antar individu yang membentuk masyarakat sosial dengan

30 Goorge Ritzer, Teori Sosiologi Modern...,hlm. 265. 
teratur dan tertib. Jika sikap individu lebih mementingkan dir inya maka akan terjadi berbagai problematika yang muncul dari masyarakat sosial dengan berbagai tafsirannya. Termasuk kecaman dari Nitizen menganggap bahwa tulisan Arab dibusana Agnes Mo merupakan simbol agama. Sedangkan MUI menilai busana Agnes Mo tidak mencitrakan busana adat ketimuran, terlalu vulgar, dan transparan.

\section{DAFTAR PUSTAKA}

Sumber Buku:

Daniel El Pals, Dekontruksi Kebenaran: Kritik Tujuh Teori Agama, penerjemah: Inyiak Ridwan Muzir, M Syukri, penyunting: Edi AH Iyubenu, judul asli Seven Theories of Religion, Yogyakarta: IRCiSoD, 2003.

Hudjolly. Imagologi: Strategi Rekayasa Teks. Yogyakarta: Ar-Ruzz Media, 2011. Narwoko, Dwi, Bagong Suyanto, Sosiologi, Teks Pengantar dan Terapan, edisi kedua, cet.3. Jakarta: Kencana, 2007.

Ritzer, Goorge. Teori Sosiologi Modern, edisi ke tujuh, penerjemah Triwibowo, buku asli berjudul Modern Sociological Theory: Seventh Edition. Jakarta: Kencana, 2014.

Internet:

https://id.m.wikipedia.org/wiki/Daftar 99 wanita paling berpengaruh di I ndonesia_(2007)

https://www.google.com/amp/s/beritagar.id/artikel-amp/seni-

hiburan/menyimak-kontroversi-teks-arab-dalam-kostum-agnesmonica

https://www.bbc.com/indonesia/majalah/2016/01/160113 trensosial bus ana arab agnesmonica

http://www.suara.com/entertainment/2016/01/12/184537/pernyataanmui-soal-heboh-tulisan-arab-di-busana-agnez-mo

http://www.bintang.com/celeb/read/2410337/mui-angkat-bicara-soaltulisan-arab-di-kostum-agnes-monica

https://www.google.com/amp/s/m.liputan6.com/amp/2410284/muikomentari-baju-berbahasa-arab-agnes-monica

https://www.google.com/amp/s/m.bintang.com/amp/2410337/muiangkat-bicara-soal-tulisan-arab-di-kostum-agnes-monica 